\title{
血尿，蛋白尿を呈する患者の腎生検による臨床病理学的検討
}

\author{
徳山中央病院泌尿器科（主任：林田重昭博士） \\ 篠原 陽一 三井 博 那須 誉人 林田 重昭

\section{CLINICOPATHOLOGICAL STUDY OF PATIENTS PRESENTING HEMATURIA AND PROTEINURIA BY RENAL BIOPSY}

\author{
Yoichi Shinohara, Hiroshi Mitsui, Takahito Nasu and Shigeaki Hayashida \\ Department of Urology, Tokuyama Central Hospital \\ (Chief: S. Hayashida, M.D.)
}

We performed 308 series renal biopsies during 4 years (1985-1989) and 289 cases were examined by light microscopic, electron microscopic, or immunofluorescent study. Clinically, chronic nephritic syndrome was most frequent $(55.4 \%)$, followed by nephrotic syndrome (15.1\%), and recurrent or persistent hematuria (12.8\%). Pathologically, IgA nephropathy was most popular (39.3\%), followed by normal glomerulus $(9.1 \%)$, and thin basement membrane disease (8.7\%). Glomerulonephritis clinically recognized with recurrent or persistent hematuria, hardly showing proteinuria, in $81.6 \%$ of the cases, consisted of normal glomerulus, or thin basement membrane disease by electron microscopic and immunofluorescent examinations. The remainder (18.4\%) was with IgA nephropathy, which was histologically mild. On the other hand, cases of chronic nephritic syndrome (latent type) with persistent proteinuria and hematuria were with glomerulonephritis of various types including IgA nephropathy in $78.8 \%$ of the total cases. Therefore, proteinuria is an important sign of glomerulonephritis.

In investigation in different age groups, IgA nephropathy was seen in about $40 \%$ of both pediatric and adult cases, whereas minor glomerular abnormalities and thin basement membrane disease were more frequent in pediatric cases. Tubulo-interstitial lesions and glomerular lesions in vascular or metabolic diseases were recognized more in adults than in children. Membranous glomerulonephritis (17 cases including 4 pediatric cases), complicated with malignant tumors such as bladder or rectal cancers and hepatoma was found in 3 aged patients. Examination for malignant tumor would be necessary for aged patients with membranous glomerulonephritis.

As for the prognosis of IgA nephropathy, because histological changes of IgA nephropathy varied widely from very mild state to severe state, the prognosis is not always good. Histological changes tended to be the more severe, the more intense was proteinuria.

As for the complications of renal biopsy, macroscopic hematuria was recognized in about $5 \%$ of the cases, but there were no severe complications.

Key words: renal biopsy, chlinico-pathological study

\footnotetext{
要旨：1985年12月より1989年12月までの 4 年間に, 腎生検を施行した 308 症例のらち, 病理学的診断が可 能であったのは298症例であった。これらの症例の臨床診断としては, 慢性腎炎症候群が165例と最も多 く全体の $55.4 \%$ を占めていた。ついでネフローゼ症候群，反復性をたは持続性血尿の順であった。病理 診断では, IgA 腎症が117例と最も多く全体の $39.3 \%$ 占めていた. 臨床診断と病理診断の関連性につい て検討してみると，血尿が主体で蛋白尿はほとんど認めない反復性または持続性血尿では， $81.6 \%$ 症 例においていわゆる系球体腎炎は認められず，予後良好と思われる正常系球体か，基底膜菲薄症であっ た. 残りの $18.4 \%$ 症例は IgA 腎症であったが, 組織学的に傷害の高度なものは 1 例もなかった.

一方, 持続する蛋白尿と血尿を主体とする慢性腎炎症候群（潜在型）では， IgA 腎症をはじめとする
} 
糸球体腎炎が全体の $78.8 \%$ 占めており組織学的に傷害の高度なものも含まれていた。従って，臨床所 見としての蛋白尿の重要性が確認された，年龄別にみると，IgA 腎症は小児例，成人例ともに約 $40 \%$ に みられたが，正常糸球体例と基底膜菲薄症は小児例に多く認められた。17例の膜性腎症（小児例 4 例を 含む) のらち, 高齢者の 3 例に膀胱腫瘍を含む悪性腫瘍の合併が認められ, 注意が必要と思われた。 キーワード：腎生検, 臨床及び病理学的検討

\section{緒言}

近年，学校や職場に打ける集団検診の普及などによ り，血尿や蛋白尿などの尿検査異常や腎機能障害を指 摘され医療機関を受診する患者が増加してきている。 その際, まず最初に泌尿器科医が DIP や膀胼鏡などの 検査を行ない, 腫瘍や結石などの泌尿器科的疾患の有 無についての検索を行ならことが大切である，泌尿器 科的検索で異常を認めなかった症例が，将来腎不全に 進行する可能性のあるものか，長期間観察しても悪化 しないものかを鑑別することは，糸球体病変を中心と する腎疾患を管理するらえで大切なことである。さら に治療方針の決定に役立つ客観的情報も必要である。 そのためには腎生検を施行し病理学的診断をつける必 要がある．われわれの施設では，この様な考方方に基 づいて, 治療の一貫性を高めるために泌尿器科医が腎 生検を施行してきた。今回，1985年12月より1989年12 月までの 4 年間に, 当科で腎生検を施行した 308 症例の ち病理学的診断が可能であった298症例について臨 床病理学的検討を行なったので報告する。

\section{対象}

1985年12月から1989年 12 月までの 4 年間に当科で腎 生検を施行した 308 症例のうち, 光顕所見, 電顕所見, 蛍光抗体染色所見がそろって病理学的診断が可能で あった298症例を対象とした。その内，同一症例に時期 をずらして腎生検を施行した症例が 7 症例含まれてい た。当科における腎生検の適応を表 1 に示した。原発 性系球体疾患が疑われる症例のみでなく，続発性系球

表 1 徳山中央病院泌尿器科に括ける腎生検の適応

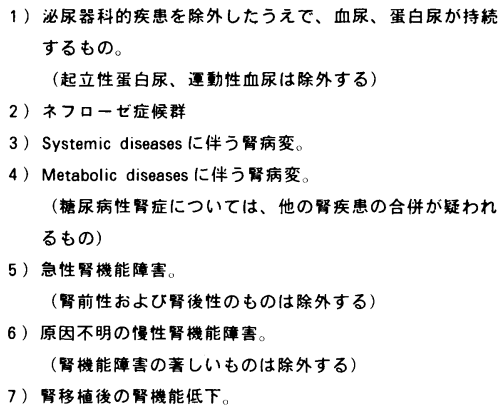

図 1 腎生検を施行した298例の年齢分布

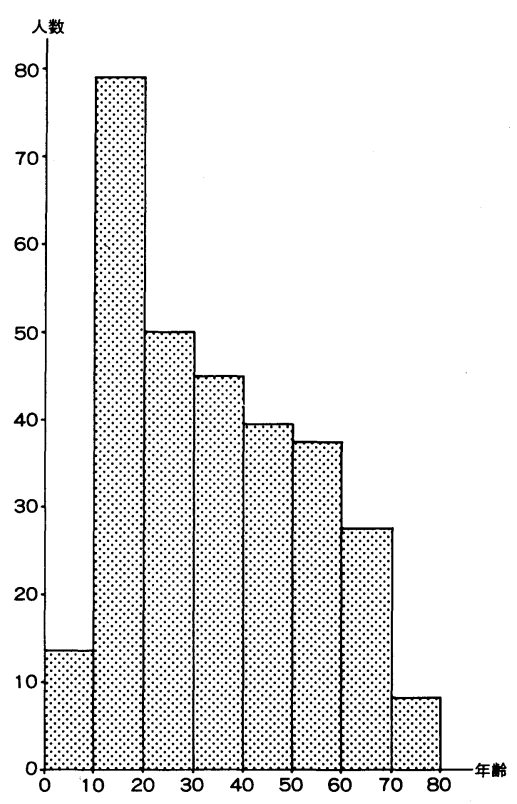

体疾患が疑われる症例についても病変の程度を知るた めに腎生検を施行した。また急性腎機能障害や原因不 明の慢性腎機能障害に対しても積極的に腎生検を施行 し病理診断をつけるように努めた。性別は男性150例， 女性148例で, 生検時年齢は $2 \sim 77$ 歳(平均34歳)であっ た。年齢分布は図 1 にしめしたように 10 代が最も多く， 全体のほぼ25\%を占めていた。

\section{方法}

腎生検は，超音波ガイドのもと14G の True-Cut 針 （トラベノール社）用いて施行したが，1989年 7 月以 降は $18 \mathrm{G}$ 針を使用する Biopty（バード社）を用いて機 械的に施行した(後述)。確実に腎組織を採取するため に，光䫓標本，電顕標本，蛍光抗体染色標本をそれぞ れ別々に生検し，十分な組織標本が得られる様に努め た。標本はただちに福岡大学第 2 病理学教室に送り病 理学的診断を仰いだ。個々の患者の臨床経過と腎生検 結果はパソコンのデータベースを用いて管理した。腎 生検の結果について統計的観察を行なうとともに，臨 
床診断と病理診断の関連性についても検討した。

\section{結 果}

腎生検施行前に WHO の臨床症候群の定義に準拠 してつけた臨床診断を表 2 に示した。 WHO の臨床分 類, 組織分類 ${ }^{1}$ は, 糸球体を中心とする病変についての みであり，腎疾患の全体を網羅したものではない，今 回の上らに尿検査異常や腎機能障害を示寸症例に腎生 検を施行すると, 当然, 系球体病変のみでなく間質や 尿細管の病変も出現してくる，われわれは，出来るだ けWHO の分類に従いながら，間質や尿細管の病変も 含まれるように分類を行なった. WHO では, 慢性腎炎 症候群を血尿，蛋白尿，高血圧を呈し，緩徐に腎不全 に進行する症候群と定義しているが，我が国では，血 尿，蛋白尿が長期間持続しても腎機能が低下しないも

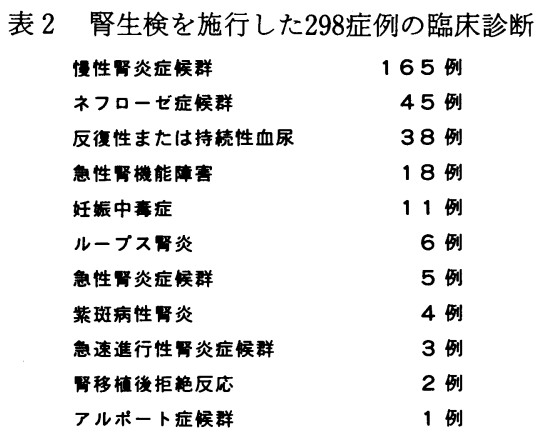

表 3 腎生検を施行した298症例の病理診断

$\begin{array}{lrll}\text { IgA nephropathy } & 1 & 17 \text { 例 } \\ \text { Normal glomerulus } & 27 \text { 例 } \\ \text { Thin basement membrane disease } & 26 \text { 例 } \\ \text { Membranous glomerulonephritis } & 17 \text { 例 } \\ \text { Mesangial proliferative glomerulonephritis } & 12 \text { 例 } \\ \text { Minimal change lipoid nephrosis } & 10 \text { 例 } \\ \text { Nephropathy of toxemia of pregnancy } & 10 \text { 例 } \\ \text { Vascular nephrosclerosis } & 10 \text { 例 } \\ \text { Lupus nephritis } & 9 \text { 例 } \\ \text { Interstitial nephritis } & 8 \text { 例 } \\ \text { Focal glomerulosclerosis } & 7 \text { 例 } \\ \text { Acute tubular necrosis } & 7 \text { 例 } \\ \text { Diabetic nepropathy } & 6 \text { 例 } \\ \text { Chronic pyelonephritis } & 6 \text { 例 } \\ \text { Crescentic glomerulonephritis } & 5 \text { 例 } \\ \text { Purpula nephritis } & 4 \text { 例 } \\ \text { HB virus nephritis } & 4 \text { 例 } \\ \text { Endocapillary proliferative glomerulonephritis (AGN) } & 3 \text { 例 } \\ \text { Membranoproliferative glomerulonephritis } & 2 \text { 例 } \\ \text { Sclerosing glomerulonephritis } & 2 \text { 例 } \\ \text { Renal amyloidosis } & 2 \text { 例 } \\ \text { Alport's syndrome } & 1 \text { 例 } \\ \text { Others } & 3 \text { 例 }\end{array}$

の（潜在型）も含めて慢性腎炎症候群として扱うこと が多いので,われわれもそれに従った.WHO が定義す るものは，我が国の進行型に該当することになる2).

臨床診断では, 慢性腎炎症候群が165例と全体の 55.4\%を占めていた。 ついでネフローゼ症候群, 反復 性または持続性血尿の順であった，急性腎機能障害 18 例のらち 8 例が薬剤性腎機能障害であった。抗生剤に 起因するものが 4 例と最も多く，そのほかシスプラチ ンによるものが 2 例，パラコートとシンナーによるも のがそれぞれ 1 例であった。急速進行性腎炎症候群は 3 例経験した。生体腎移植後に腎機能低下を来たした 2 症例にも腎生検を施行し，サイクロスポリンによる 腎障害の有無などを検討した。

病理学的診断結果を表 3 に示した. IgA 腎症が 117 例 と最も多く全体の $39.3 \%$ を占めていた。 ついで正常糸 球体群が27例, 基底膜菲薄症：Thin membrane disease (TMD) が26例であった。ここで正常糸球体 (Normal glomerulus)としたものは，光顕所見で正常 または微小変化像を呈し，蛍光抗体法による検索では 免疫グロブリン，補体また Fibrin/Fibrinogen 等がす べて陰性を示し, 電顕的には dense deposit は認めず, 足突起の疻合もなく，系球体基底膜の幅も正常範囲に 保たれていた症例である。IgA 腎症では膠原病，紫斑 病，肝疾患などによる二次性のものは除外した。一方， ループス腎炎や紫斑病性腎炎などの全身疾患に伴ら系 球体病変は, 臨床像をふまえて病理学的診断を打こ なった。膜性腎炎は17例 (5.7\%) に認められたが，膜 性増殖性系球体腎炎はわずか 2 例 $(0.7 \%)$ にみられた のみで, type 1 と type 3 1 例ずつであった。最も頻 度の高い IgA 腎症の発見の動機としては, 健康診断や 人間ドックで発見された，いわゆる chance proteinuria が31.8\%と最も多く，これと chance hematuria 拉 よび chance proteinuria \& hematuria を合わせると 全体の $79.5 \%$ 占め，患者の自覚症状により発見され る症例の割合は少なかった。性別は男性61例，女性56 例で，発症年柃は図 2 に示したように，10歳代から40 歳代にかけて幅広く発症していた。ひとまとめに IgA 腎症といってもその系球体病変は軽度なものから高度 のものまで様々であった，光顕所見に基づく糸球体病 変の分類結果を図 3 に示した。軽度の糸球体病变を有 するものが最も多かったが，中等度以上の症例も全体 の17.1\%に認められた。117例の IgA 腎症のらち血液 透析に移行した症例は 4 例で, 中等度の系球体病変を 有するものが 2 例, 高度の糸球体病変を有するものが 
因 $2 \quad \operatorname{IgA}$ 腎症117例の年齢分布

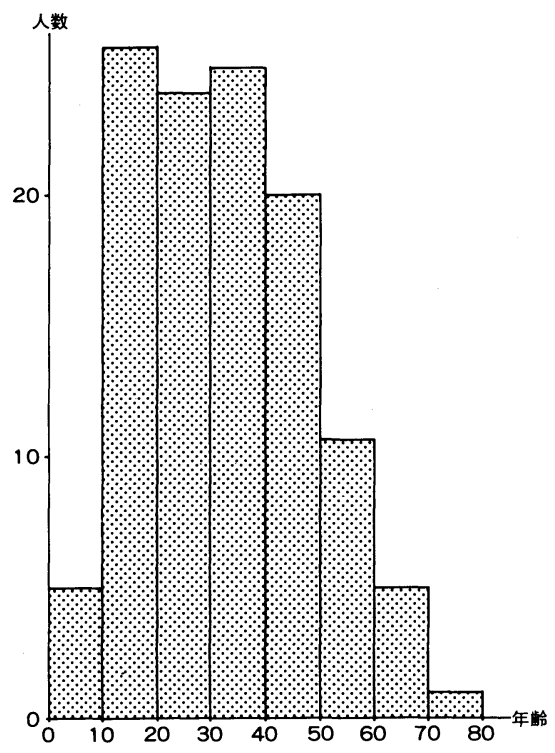

2 例であった。WHOの基準により高血圧を160/95 $\mathrm{mmHg}$ 以上とすると 4 例とも高血圧症例であった。

15歳以下の小児症例と, 16歳以上の症例にわけて, 臨床診断と病理診断の分布について検討した（図 4, 図 5 ). 臨床的には区復性または持続性血尿が小児症例 で25.5\%を占め, 16 歳以上の症例のおよそ2 倍に達し た。ループス腎炎や紫斑病性腎炎などの頻度にも差を 認めたが，これは主に好発性年齢の差に起因するもの と考えられた。慢性腎炎症候群はともに約 $50 \%$ を占め ており, , 小児症例と 16 歳以上の症例の間で差を認めな かった。病理診断では正常系球体と TMD が小児症例 の $19 \%$ と $17 \%$ 占めており，これは 16 歳以上の症例の 2 倍以上の割合であった。

IgA 腎症はともに約40\%を占めており両者の間で差 を認めなかった. Vascular disease や Metabolic disease に伴う系球体病変は16歳以上の症例にの及認め たが, Systemic disease に伴う腎炎の頻度はほぼ同じ

図 3 IgA 腎症117例の光顕所見による分類

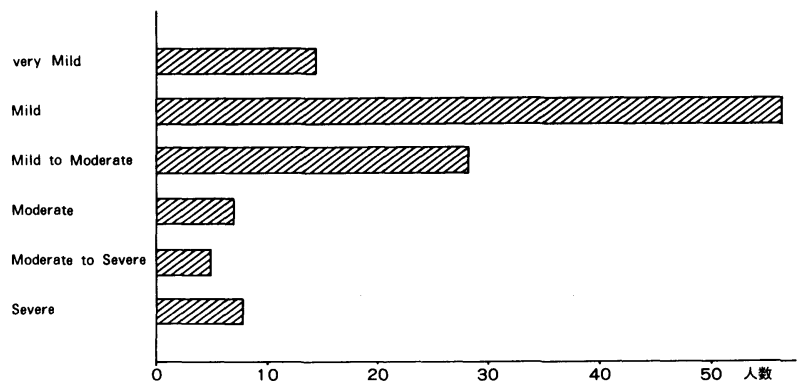

図 4 年齢別にみた臨床診断

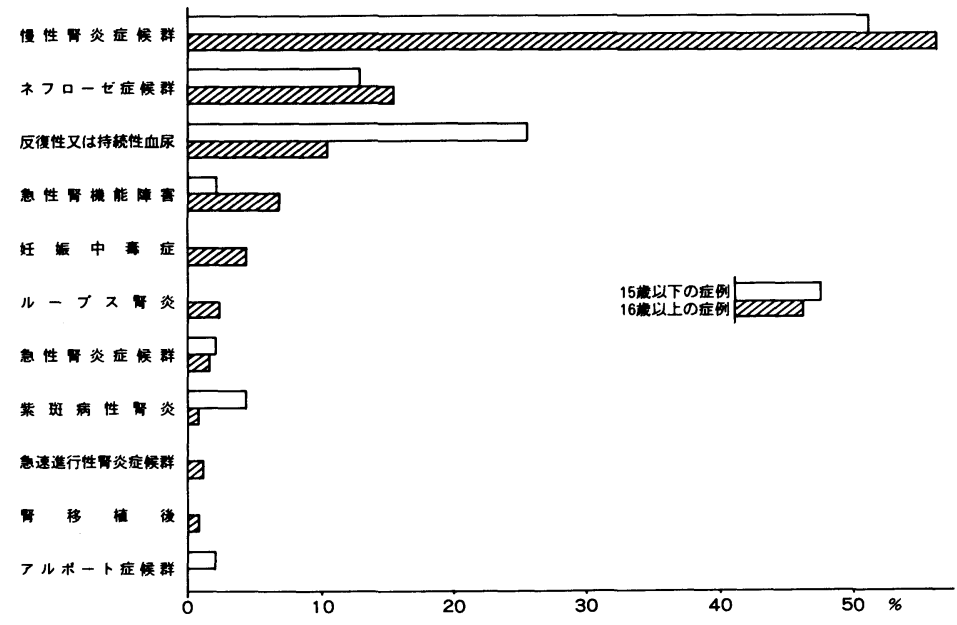


図 5 年齢別にみた病理診断

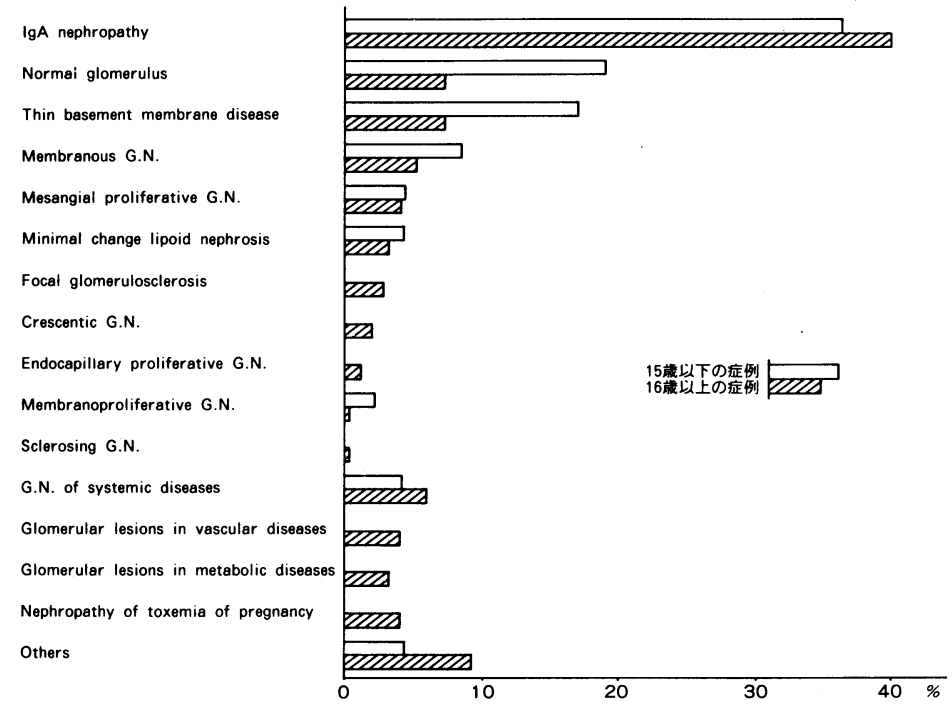

表 4 慢性腎炎症候群（腎機能低下症例を除外する） と臨床診断して腎生検を施行した151症例の病理診 断

IgA nephropathy
Normal glomerulus
Thin basement membrane disease
Mesangial proliferative glomerulonephritis
Vascular nephrosclerosis
Membranous glomerulonephritis
Grescentie glomerulonephritis
Chronic pyelonephritis
Focal glomerulosclerosis
HB virus nephritis
Interstitial nephritis
Diabetic nephropathy
Renal amyloidosis

Renal amyloidosis

$\begin{array}{rrr}1 & 0 & 1 \\ 1 & 1 & \text { 例 } \\ 9 & \text { 例 } \\ 7 & \text { 例 } \\ 5 & \text { 例 } \\ 4 & \text { 例 } \\ 3 & \text { 例 } \\ 3 & \text { 例 } \\ 2 & \text { 例 } \\ 2 & \text { 例 } \\ 2 & \text { 例 } \\ 1 & \text { 例 } \\ 1 & \text { 例 }\end{array}$

であった。な拉，その他に分類されていれのは，間質 性腎炎をはじめとする種々の間質および尿細管病変で ある。

血尿と蛋白尿を主体とする慢性腎炎症候群（腎機能 障害をみとめる症例は省く）と, 血尿が主体で蛋白尿 はほとんど認めない反復性または持続性血尿につい て, 臨床診断と病理診断の分布を検討した（表 4 , 表 5 ). 反復性または持続性血尿之臨床診断した 38 症例 中, TMD は17例 (44.7\%), 正常系球体14例 (36.8\%) で，系球体腎炎としては IgA 腎症を 7 例 (18.4\%) に 認めたのみであった。これらは光顕的には, 軽度のも のが 6 例, 軽度から中等度のものが 1 例で, 組織学的
表 5 反復性又は持続性血尿と臨床診断して腎生検を 施行した 38 症例の病理診断

$\begin{array}{lr}\text { Thin basement membrane disease } & 17 \text { 例 } \\ \text { Normal glomerulus } & 14 \text { 例 } \\ \text { IgA nephropathy } & 7 \text { 例 }\end{array}$

に高度な傷害例は 1 例もみられなかった。一方, 慢性 腎炎症候群と臨床診断した症例のらち腎機能障害を伴 ら15症例を除外した151症例では, IgA 腎症101例 (66.9\%)をはじめとして，系球体腎炎が全体の78.8\% を占めていた。 その組織像は軽度のものから高度なも のまで様々であった。ささら高血圧や代謝性疾患に伴 万腎病変や間質性腎炎を12例(7.9\%)に認めた。逆に, 正常系球体例は14例 (9.3\%), TMD は 9 例 (6.0\%) にすぎなかった。

大量の蛋白尿, 低アルブミン血症, 浮腫を主体とす るネフローゼ症候群（妊娠中毒症によるものは除く） 45症例の病理診断結果を表 6 に示した。原発性腎疾患 に起因する一次性ネフローゼ症候群が77.8\%を占めて おり, 続発性腎疾患による二次性ネフローゼ症候群は $22.2 \%$ あった。疾患別分類では膜性腎症が14例 (31.1\%) と最も多く，ついで minimal change nephrotic syndrome (MCNS) が10例 (22.2\%), ルー プス腎炎と Focal glomerulosclerosis（FGS）がそれ ぞれ 4 例 (8.9\%) であった。年齢別にみると小児症例 が 6 例，16歳以上の症例が39例であった。 全小児症例 
表 6 ネフローゼ症候群と診断した 45 症例の病理診断

$\begin{array}{lr}\text { Membranous glomerulonephritis } & 14 \text { 例 } \\ \text { Minimal change lipoid nephrosis } & 10 \text { 例 } \\ \text { Focal glomerulosclerosis } & 4 \text { 例 } \\ \text { Lupus nephritis } & 4 \text { 例 } \\ \text { IgA nephropathy } & 3 \text { 例 } \\ \text { Mesangial proliferative glomerulonephritis } & 2 \text { 例 } \\ \text { HB virus nephritis } & 2 \text { 例 } \\ \text { Diabetic nephropathy } & 2 \text { 例 } \\ \text { Others } & 4 \text { 例 }\end{array}$

中に怙けるネフローゼ症候群の割合は $12.6 \%$ であり， 16歳以上の症例におけるそれは $15.5 \%$ あった。 小児 例では，膜性腎症と MCNS がそれぞれ $33.3 \%$ 占め ていたが，16歳以上の症例では膜性腎症が $28.2 \%$ と最 も多く, MCNS は20.5\%であった。ついでループス腎 炎と FGS がともに10.5\%を占めていた。

明らかな腎前性もしくは腎後性の原因を有しない， 急性腎機能障害18症例に対しても腎生検を施行した。 腎機能が $1 \sim 2$ カ月以内にクレアチニンクリアランス (Ccr) で30l/day 以下に低下したもののうち, 臨床的 に急性進行性腎炎症候群または急性腎炎症候群と診断 した症例を除外したものを，急性腎機能障害として 扱った。表 7 に病理診断結果を示した。急性腎機能障 害のらち 7 例 (38.9\%) が急性尿細管壊死で，その内 5 例が薬剤性のものであった。 薬剤としてはセファ口 スポリン系抗生剤が 2 例で, アミノグリコシド系抗生 剂と自殺未遂のパラコートが 1 例ずつであった。 その ほか卵巣腫瘍の手術中にシスプラスチンを腹腔内投与 した症例が 1 例あった。術中投与は出血もあり，十分 な水分負荷をかけることが難しいことが原因のひとつ と考えられた。薬剤性の間質性腎炎を 3 例に認めた。 特殊な症例としては, 蝮咬傷後に急性腎不全に陥り緊 急透析を施行した症例を経験した。計14回の血液透析 を施行したのち離脱可能となったが，腎生検の結果は 軽度の尿細管壊死を伴 う高度の半月体形成性腎炎で あった。

高齢者の膜性腎症の原疾患として少なからず大腸癌 や肺癌などの悪性腫瘍がみいだされているが3(4)，われ われも17例の膜性腎症（小児例 4 例を含む）のうち 3 例に悪性腫瘍をみとめた。そのうちの 2 例は, 膜性腎 症に起因するネフローゼ症候群に対し，ステロイド療 法を施行中に大腸癌をみとめた 57 歳の症例と, 肝癌を みとめた 76 歳の症例であった。残る 1 例は膀胖腫瘍の ため化学療法, 放射線療法, 経尿道的膀胖腫瘍切除術 などの泌尿器科的治療をらけて腫瘍消失した後に, 外
表 7 急性腎機能障害18例の病理診断

$\begin{array}{ll}\text { Acute tubular necrosis } & 7 \text { 例 } \\ \text { Minor glomerular abnormalities } & 3 \text { 例 } \\ \text { Interstitial nephritis } & 2 \text { 例 } \\ \text { Endocapillary proliferative glomerulonephritis(AGN) } & 1 \text { 例 } \\ \text { Crescentic glomerulonephritis } & 1 \text { 例 } \\ \text { Cortical necrosis (DIC) } & 1 \text { 例 } \\ \text { Others } & 3 \text { 例 }\end{array}$

来で経過観察を行なっていた71歳の症例であった。術 後およそ半年経過した頃より，しだいに蛋白尿が高度 となってきたため腎生検を施行したところ膜性腎症で あった，高龄者が膜性腎症と診断された場合には，積 極的に悪性腫瘍の検索を行なら必要があると思われ た。

SLE において, 堅生検が予後判定や治療方針の決定 に有効か否かについては議論があるが5(5), SLEでは腎 病変を合併することが多く, その程度が予後に大きく 影響していることは間違いない. 従ってわれわれは, SLE に対しても積極的に腎生検を施行しており，9例 を経験した。

合併症としては，1985年12月より1989年 6 月までは 超音波ガイド下に14G の True-Cut 針を用いて腎生検 を施行したが，肉眼的血尿を $4.6 \%$ に, 後腹膜血腫を $2.8 \%$ の症例に認めた。 また移植腎を生検した 1 例で動 静脈瘻を認めた。輸血を必要とした症例は 2 例であっ た. 1989年 7 月以後は, Bioptyを使用して腎生検を施 行したが, 肉眼的血尿を $3.7 \%$ 症例に認めた。輸血を 必要とした症例は認めなかった。

\section{考察}

腎生検の結果を他の施設の結果と比較検討する場 合, 病理診断が正確なことは当然のこととして, 結果 の差のかなりの部分は腎生検の適応基準の差によるも のであることを忘れてはならない77 9). また同一施設 においても症例を重ねるにつれて, 臨床所見より判断 して組織所見が軽度と考えられる症例に対しては，し だいに腎生検を施行しなくなる傾向にあると思われ る. 今回のわれわれの施設における集計では, 始めに 適応を決めて招き可能なかぎり該当する症例には腎生 検を施行するよう努めた。しかしながら，小児の症例 に関しては，小児科医の紹介により腎生検を施行した 症例も含まれて打り，必ずしも上述した適応のと打り ではなかった。 小児のネフローゼ症候群の大部分は MCNS であり, ステロイドが有効であると言われてい る ${ }^{10111}$. 従って，まず小児科でステロイド療法を受け， 難治性をたは頻回再発性の症例が当科紹介となって腎 
生検を施行されている.今回の集計で, 小児のネフロー ゼ症候群における MCNS の割合が $33.3 \%$ と低くでて いるのはその結果と考えられた。

今回，腎生検の集計を抗こなってみてあらためて感 じたことは, 臨床所見としての蛋白尿の重要性である. 血尿が主体で蛋白尿をほとんど認めない反復性または 持続性血尿では $81.6 \%$ 症例に扣いて，いわゆる糸球 体腎炎は認められず，予後良好な正常系球体か TMD であった。残りの $18.4 \%$ 症例が IgA 腎症であった が，組織傷害度が高度なものはみられなかった。 また 血尿の程度の強さと IgA 腎症の存在の有無の間には 明らかな関係を認めなかった。一方，持続する蛋白尿 と血尿を主体とする慢性腎炎症候群（腎機能がすでに 低下している症例は除外した)。では, IgA 腎症をはじ めとする糸球体腎炎が逆に全体の78.8\%を占めてい た。また大量の蛋白尿を特徵とするネフローゼ症候群 では，すべての症例に招いて糸球体病変を認めた。以 上の結果より蛋白尿が持続する症例に対しては, 積極 的に腎生検を施行し病理診断をつけたうえで，患者指 導を含む治療, 経過観察を行なら必要があると思われ た。血尿が主体で蛋白尿はほとんど認めない症例では $18.4 \%$ IgA 腎症を認めたが, 組織傷害度が高度なる のはみられなかった。このような症例をどら取扱らか には議論があると思われるが12113)，全身疾患に伴う場 合や腎機能障害を認めるような特殊な症例を除外すれ ば，まず定期的な経過観察を行ない，もし蛋白尿が持 続するよらになれば腎生検を考慮するのが良いのでは ないかと考学ている。しかしながら泌尿器科的疾患を みとめない若年者に比較的大量の血尿が持続する場合 には，医師としての責任のもてる生活指導を患者に行 ならためにも腎生検が必要であると思われた。この様 な症例に対しての必要以上の安静療法（長期入院, 体 育の全面的禁止など）は，病理診断のららづけがない かぎり安易に施行してはならないと考光ている。

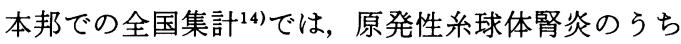
成人の $30 \%$, 小児の $19.2 \%$ IgA 腎症と報告されてお り，本症は最も頻度の高いものである。また諸外国で も頻度の高いことが報告されており ${ }^{15)}, \operatorname{IgA}$ 腎症は重 要な腎炎といえる。IgA 腎症は, 報告された初期には 血尿を主体とする比較的予後良好な疾患と言われてい たが，長期観察例がふえるにつれ腎不全に進行する症 例も報告されるよらになってきた ${ }^{16177}$. Rodicioは 10 20\%が腎不全に宿り， 5 年生存率は 90 ～95\%，10 年生存率は $80 \sim 85 \%, 20$ 年生存率は $50 \sim 70 \%$ と報告し
ている ${ }^{18)}$.しかし今回の集計から, IgA 腎症の糸球体病 変の程度には大きなばらつきがあり，ひとまとめにし て予後についての議論はできないと思われた。光顕所 見に基づく糸球体病変が中等度以上の 20 症例のうち 4 例 $(20 \%)$ が血液透析に移行したが，系球体病変が中 等度以下の症例では血液透析に移行した症例は現在の ところみとめていない，糸球体病変が中等度以上の症 例については, 血圧のコントロールを含む厳重な経過 観察が必要と思われた。

腎生検の手技としては，1989年 6 月までは超音波ガ イド下に14G の True-Cut 針を用いて腎生検を施行し た. 1989年 7 月以後は, Bioptyを使用して腎生検を施 行した。この自動穿刺装置には強力なバネが内臓され ており，その力により内套を組織内に押し進めたのち 外套を挿入して組織を採取するという2 段階の操作を ボタンひとつで瞬時に行ならことが出来る装置であ る. $18 \mathrm{G}$ 針を使用しているが，光顕標本において平均 11.7個の糸球体が採取されて招り病理診断用としては 十分な組織が得られた. True-Cut 針と比較して半分の 外径 $(1.2 \mathrm{~mm})$ であり，また生検が瞬間的に行なわれ るため出血の危険性が若干少ないように思われた。文 献によると，腎生検の成功率は 80 ～95\%，合併症は 5 〜 10\%と考号られているが ${ }^{19220)}$ ，われわれの成功率は $96.8 \%$ とほぼ満足できるものであった。成功率を高め るには，ひとつの組織標本を 3 分割するのではなく， 光顕標本, 電䫓標本, 蛍光抗体染色標本をそれぞれ別々 に生検し，十分な組織標本を得る様に努めることが大 切と思われた。 この様な方法を用いても，諸家の報告 に比べて合併症が増加することはなかった。

以上，1985年12月より1989年12月までの 4 年間に, 当科で腎生検を施行した 308 症例について臨床病理学 的検討を行なった。

稿を終えるにあたり，御指導, 御校閲を賜った福岡大学第 2 病理学教室, 竹林茂夫教授, ならびに田口尚助教授に深謝 申し上げます。

\section{文献}

1) Churg, J. and Sobin, L.H.: Renal disease. Classification and atlas of glomerular diseases. Igakushoin, Tokyo, New York, 1982.

2）荻野宗次郎, 丸山雄一郎, 甲田 豊, 荒川正昭: 系 球体腎炎の診断。診断と治療, 75，2370-2374, 1987.

3) Lee, J.C., Yauchi, H. and Hopper, J.: The association of cancer and the nephrotoic syndrome. Ann. Inter. Med., 64, 41-51, 1966. 
4) Pascal, R.\$.: Renal manifestations of extrarenal neoplasms. Human Pathol., 11, 7-17, 1980.

5) Fries, T.F., Porta, J. and Liang, M.H.: Marginal benefit of renal biopsy in systemic lupus erythematosus. Arch. Inter. Med., 138, 1386 $-1389,1978$.

6) Kimberly, R.P., Lockshin, M.D., Sherman, R.L., Beary, J.F., Mouradian, J. and Cheigh, J.S.: "End-stage" lupus nephritis: Clinical course ot and outcome on dialysis. Medicine, 60, 277-287, 1981.

7）荒川正昭, 阿部昌洋：腎生検の適応とその限界. 診 断之治療, 72, 2214-2219, 1987.

8）岡田正昭：腎正検の臨床的意義. 最新医学, 39, 2234-2238, 1984.

9）大沢源吾：腎炎管理からみた腎生検の必要性. Mdical Practice, 4, 595-599, 1987.

10) Arneil, G.C.: The nephrotic syndrome. Pediatr. Clin. North Am., 18, 547-559, 1971.

11) Churg, J., Habib, R. and White, R.H. R.: Pathology of the nephrotic syndrome in children. A report for the international stydy of kidney disease in children. Lancet, 1, 1299 $-1302,1970$.

12) Michael, J., Jones, N.F., Davies, D.R. and Tighe, J.R.: Recurrent haematuria: role of renal biopsy and investigative morbidity. Brit. Med.
J., 1, 686-688, 1976.

13）伊藤克己, 長田道夫：学校検尿および chance proteinuria一特に腎生検の手技执よび意義につ いて一。少科臨床，39，2768-2774，1987.

14）北島武之，酒井 紀，村上睦美：わが国における IgA 腎症の実態. 日腎会誌，24，735-737，1982.

15) Power, D.A., Muirhead, N., Simpson, J.G., Nicholis, A.J., Horne, C.H.W., Catto, G.R.D. and Edward, N.: IgA nephropathy is not a rare disease in the United Kingdom. Nephron, 40, 180-184, 1985

16) Abe, T., Kida, H., Yoshimura, M., Yokoyama, H., Koshino, Y., Tomosugi, N. and Hattori, N : Participation of extracapillary lesios (ECL) in progression of IgA nephropathy. Clin. Nephrol., 25, 37-41, 1986.

17) Chida, Y., Tomura, S. and Takeuchi, J.: Renal survival rate of IgA nephropathy, Nephron, 40, 189-194, 1985.

18) Rodicio, J.L.: Idiopathic IgA nephropathy. Kid. Int., 25, 717-729, 1984.

19) Wickre, C.G. and Golper, T.A.: Complications of percutaneous needle biopsy of the kidney. Am. J. Nephrol., 2, 173-178, 1982.

20）阿部昌洋, 荒川正昭：堅生検法, 新腎炎のすべて, p62-71, 南江堂, 東京, 1983.

（1990年 9 月 18 日受理） 